\title{
Obstructive sleep apnea syndrome and sleep quality in hypertensive patients
}

\author{
Marcelo Rodrigues Bacci ${ }^{1}$, Jonathan Naim Mora Emboz ${ }^{1}$, Beatriz da Costa Aguiar Alves ${ }^{2 *}$, Glaucia Luciano da Veiga ${ }^{2}$, \\ Neif Murad ${ }^{1}$, Adriano Meneghini ${ }^{1}$, Antonio Carlos P. Chagas ${ }^{1}$, Fernando Luiz Affonso Fonseca ${ }^{1,2}$
}

Study conducted at Faculdade de Medicina do ABC, Santo André, SP, Brazil

Article received: $4 / 18 / 2017$ Accepted for publication: 5/22/2017

\section{SUMmarY}

Introduction: Obstructive sleep apnea and hypopnea syndrome (OSAHS) is one of the developmental factors of high blood pressure (HBP), a relevant global public health problem. OSAHS is characterized by the reduction or complete cessation of respiratory airflow due to intermittent airway collapse. Additionally, significant changes in sleep rhythm and pattern are observed in these patients. Objective: To evaluate the association between OSAHS and sleep quality in essential and resistant hypertensives.

Method: A cross-sectional, observational study evaluated 43 hypertensive patients treated at the outpatient clinics of the Faculdade de Medicina do ABC (FMABC) who were medicated with two or more antihypertensive drugs and divided into nonresistant or resistant to treatment.

Results: Group I (using up to two antihypertensive agents $-60.47 \%$ of the sample) presented mean systolic blood pressure (SBP) of $127.5 \pm 6.4 \mathrm{mmHg}$, mean diastolic blood pressure (DBP) of 79.6 $\pm 5.2 \mathrm{mmHg}$, mean body mass index (BMI) of $27.2 \pm 5.3 \mathrm{~kg} / \mathrm{m}^{2}$ and mean age of $51.2 \pm 15.1$ years. Group II (using more than two antihypertensive drugs $-37.2 \%$ of the sample) presented mean SBP of $132.1 \pm 9.3 \mathrm{mmHg}$, mean DBP of $84.5 \pm 5.8 \mathrm{mmHg}$, mean BMI of $27.2 \pm 7.2 \mathrm{~kg} / \mathrm{m}^{2}$ and mean age of $55.5 \pm 13.4$ years. The patients presented low quality of sleep/ sleep disorder evaluated by the Pittsburgh Sleep Quality Index (PSQI), which represents a preponderant factor for OSAHS.

Conclusion: Patients at high risk for OSAHS had poor sleep quality and high levels of DBP, suggesting a causal relation between these parameters. However, they did not present a higher prevalence of resistant high blood pressure (RHBP).

Keywords: apnea, sleep apnea syndromes, sleep apnea, obstructive, hypertension, sleep.

\section{INTRODUCTION}

High blood pressure (HBP) has a high prevalence in our country and a low control rate; it is a multifactorial clinical condition characterized by elevated and sustained blood pressure (BP) levels. ${ }^{1}$ It is one of the main modifiable risk factors and the most important public health problem. ${ }^{2}$ It is estimated that $12-15 \%$ of hypertensive patients have resistant high blood pressure (RHBP). ${ }^{3}$ RHBP is characterized as a difficult-to-manage clinical condition, associated with high cardiovascular risk. Pseudo-resistant HBP is mistaken for true RHBP due to non-adherence to treatment, inadequate blood pressure measurements, inappropriate therapeutic doses or regimens, in addition to the white coat effect. ${ }^{4,5}$ Most people with RHBP have advanced age, obesity, left ventricular hypertrophy, diabetes mellitus, chronic nephropathy, metabolic syndrome, an increased salt intake, are from African descent and less physically active. There are several causal factors for RHBP, with obstructive sleep apnea and hypopnea syndrome (OSAHS) being the most common causes ${ }^{6,7}$ OSAHS is characterized as the reduction in or complete cessation of respiratory airflow due to intermittent airway collapse, 
despite sustained respiratory effort. ${ }^{8}$ During OSAHS events, the individual presents with hypoxemia, exacerbated snoring, and recurrent micro-arousals that restore respiration and blood oxygenation.

Snoring and micro-awakenings disrupt sleep, favoring the onset of classic symptoms such as excessive daytime sleepiness, sensation of unrefreshing sleep, reduced ability to concentrate and fatigue. ${ }^{8}$ The apnea-hypopnea index (AHI), i.e. the mean number of apnea and hypoxia events that occur per hour, is used to assess disease severity. OSAHS is defined as AHI $\geq 5$ and is associated with excessive daytime sleepiness. ${ }^{9}$ The prevalence of OSAHS, as defined by an $\mathrm{AHI} \geq 5$ and resulting from the analysis of eleven epidemiological studies published between 1993 and 2013, averaged 22\% (range 9-37\%) in males and $17 \%$ (range $4-50 \%$ ) in females, while excessive daytime sleepiness occurred in $6 \%$ (range $3-18 \%$ ) of males and in $4 \%$ (range $1-17 \%$ ) of females. OSAHS is more prevalent in males and increases with age and obesity. ${ }^{10}$ In Brazil, there are no comprehensive studies, but the prevalence of OSAHS can be estimated in a cross-sectional study of a population sample from São Paulo. This study analyzed volunteers aged between 20 and 80 years, diagnosed with OSAHS by means of polysomnography, a gold standard for diagnosing this condition. Of 1,042 individuals selected, $55 \%$ were male and $60 \%$ had a body mass index (BMI) greater than $25 \mathrm{~kg} / \mathrm{m}^{2}$. OSAHS was diagnosed in $32.8 \%$ of individuals (95CI 29.6-36.3). The independent, OSAHS-associated factors were identified as being male $(\mathrm{OR}=4.1$; 95CI 2.9-5.8; $\mathrm{p}<0.001)$, obesity $(\mathrm{OR}=10.5$; 95CI 7.1-15.7; $\mathrm{p}<0.001)$ and age greater than 60 years $(\mathrm{OR}=34.5$; 95CI 18.5-64.2; $\mathrm{p}^{<0.001) .} .^{11}$ In each obstructive apneahypopnea event, forced inspiration against the occluded airway is accompanied by negative intra-pleural pressure. As apnea prolongs, hypoxemia and hypercapnia intensify, thereby promoting pulmonary vasoconstriction, which leads to the development of transient pulmonary hypertension. Simultaneously, there is stimulation of the sympathetic nervous system, with systemic vasoconstriction and HBP, maintaining a high level of systolic blood pressure (SBP) after an apnea event, even in individuals whose blood pressure levels are normal during wakefulness. ${ }^{12}$ In addition, the phenomenon of hypoxemia followed by subsequent reoxygenation, which repeats over and over several times during the night, cause changes in reperfusion and leads to the formation of free radicals,${ }^{13}$ oxidative stress, homocysteine and cysteine, which in turn are determining contributors to cardiovascular changes. ${ }^{14}$ An association between OSAHS and obesity, its predominance in males and in menopaused women, as well as the systemic effects triggered by its onset, strongly suggest that OSAHS is a systemic disease and not a local abnormality. Innumerable other factors are likely involved in the lesions observed in these patients, ${ }^{9,10}$ which, in the long term, promote chronic alterations in the cardiovascular system. Polysomnography, the gold standard for its diagnosis, is a high-cost test, which contributes to other diagnostic alternatives being used instead. ${ }^{12,13}$ Administering international questionnaires can estimate and predict the severity of sleep disorders by assessing excessive daytime sleepiness with the Epworth Sleepiness Scale (ESS), sleep quality with the Pittsburgh Sleep Quality Index (PSQI), and risk of OSAHS with the Berlin Questionnaire (BQ). ${ }^{14-16}$

The objective of our study was to evaluate the association between OSAHS and sleep quality in patients with essential and resistant hypertension.

\section{Method}

This is an observational, cross-sectional study with highblood-pressure patients from the outpatient clinic at Faculdade de Medicina do ABC (FMABC), who were treated with either two antihypertensive drugs (nonresistant) or more than two antihypertensive drugs (resistant).

Patients with a high blood pressure diagnosis and aged over 18 years were considered eligible to participate in the study provided they met the criteria set forth by the VI Brazilian Guidelines on Hypertension of the Brazilian Society of Cardiology. Those not adhering to the antihypertensive treatment were excluded from the study according to Morisky test, ${ }^{17,18}$ as were those affected by the white coat effect.

We used the Pittsburgh Sleep Quality Index (PSQI), comprising ten questions, to assess sleep quality. Questions number one, two, three and four are open-answer questions; whereas questions from five to ten are objective, with questions five, nine and ten having a blank space for the interviewee's comments. The PSQI questions make up seven components, which are then analyzed based on the scoring instructions for each of these components, ranging from 0 to 3 . This instrument's maximum overall score is 21 , with scores higher than 5 indicating poor sleep quality. ${ }^{16}$ This index has a sensitivity of $80 \%$, and its specificity is $68.8 \%$. We used the Epworth Sleepiness Scale (ESS) to assess the degree of daytime sleepiness. The scale consists of eight daily-life situations where the patient is asked to score between 0 and 3 their chance of napping when performing daily activities, with the following meaning: 0 , no chance of dozing off; 1 , little chance of dozing off; 2 , a fair chance of dozing off; and 3 , a high chance of 
dozing off. The scale can range from 0 to 24 . Scores above 10 denote excessive daytime sleepiness. ${ }^{19}$ In order to track the risk of OSAHS, we used the BQ, which includes 10 items, organized into three categories relative to snoring and apnea (5 items), daytime sleepiness (4 items) with a sub-question on sleepiness while driving (nap episodes at the steering wheel, while driving a motor vehicle), and high blood pressure or obesity ( 1 item). The risk-based classification (high risk versus non-high risk) relied on the responses for each category. Category I - persistent symptoms (> 3-4 times/week) on two or more questions. Category II - persistent symptoms (> 3-4 times/week), when excessive daytime sleepiness, sleepiness while driving a motorized car or both were reported. Category III - patient with a personal history of HBP or a BMI greater than $30 \mathrm{~kg} / \mathrm{m}^{2}$. Those who scored in at least two categories were considered at high risk. ${ }^{20}$

To the selected patients, we administered the Berlin, ESS and the PSQI questionnaires to assess sleep quality, OSAHS and daytime sleepiness. To assess adherence to medication intake, patients underwent the Morisky-Green Test. In addition to the questionnaires, we took ambulatory blood pressure measurement in accordance with the parameters set by the VI Brazilian Hypertension Guidelines of the Brazilian Society of Cardiology. In order to describe the characteristics studied, we used absolute and relative frequencies. We used the Chisquared test to evaluate the association between these characteristics and the risk of OSAHS with the Berlin questionnaire. The confidence level was $95 \%$. The software we used was Stata 11.0.

\section{Results}

Of the 56 interviewees, 13 displayed poor adherence to medication intake and were thus excluded from the study. Of the remaining 43 patients, $62.8 \%$ were Caucasian women $(62.8 \%)$ displaying a high adherence rate (72.1\%), most of whom did not report good sleep quality $(65.11 \%)$. Other characteristics of the population studied are shown in Table 1.

The Berlin questionnaire, which we administered in order to assess the risk of OSAHS (Table 2), showed a statistically significant association between poor sleep quality/sleep disturbance, assessed with PSQI, and a high risk of OSAHS ( $\mathrm{p}<0.037)$.

The 43 patients were divided into two groups: Group I - those who used up to two medications for treating HBP, representing $60.47 \%$ of the sample (26), and had a mean SBP of $127.5 \pm 6.4 \mathrm{mmHg}$, a mean DBP of $79.6 \pm 5.2 \mathrm{mmHg}$, a mean BMI of $27.2 \pm 5.3 \mathrm{~kg} / \mathrm{m}^{2}$ and a mean age of $51.2 \pm 15.1$ years. Group II - those who used more than two medications, totaling $37.2 \%$ of the sample (17), had a mean SBP of $132.1 \pm 9.3 \mathrm{mmHg}$, mean DBP of $84.5 \pm 5.8 \mathrm{mmHg}$, mean BMI of $27.2 \pm 7.2 \mathrm{~kg} / \mathrm{m}^{2}$ and mean age of $55.5 \pm 13.4$ years. There was no statistically significant correlation between amount of medication and poor sleep quality $(\mathrm{p}=0.4803)$. There was statistically significant correlation between a high level of DBP and the risk of OSAHS (Table 3).

\section{TABLE 1 Characterization of study variables.}

\begin{tabular}{lll} 
Characteristics & n & $\%$ \\
\hline
\end{tabular}

\begin{tabular}{lll}
\hline Sex & & \\
\hline Female & 26 & 62.8 \\
\hline Male & 17 & 37.2
\end{tabular}

\begin{tabular}{lll}
\hline Ethnicity & & \\
\hline Caucasian & 27 & 62.8 \\
\hline Non-caucasian & 16 & 37.2 \\
\hline
\end{tabular}

Epworth Questionnaire

\begin{tabular}{lll} 
Normal daytime sleepiness & 34 & 79.1 \\
\hline Excessive daytime sleepiness & 9 & 20.9
\end{tabular}

\begin{tabular}{lll}
\hline Berlin Questionnaire & & \\
\hline Low risk for OSAHS & 18 & 41.9
\end{tabular}

\begin{tabular}{lll} 
Low risk for OSAHS & 18 & 41.9 \\
\hline High risk for OSAHS & 25 & 58.1 \\
\hline
\end{tabular}

Pittsburgh Sleep Quality Index

\begin{tabular}{lll} 
Sleep quality & & \\
\hline Good & 15 & 34.9 \\
\hline Bad & 13 & 30.2 \\
\hline Sleep disorder & 15 & 34.9 \\
\hline Diabetes mellitus & & \\
\hline Yes & 8 & 18.6 \\
\hline No & 35 & 81.4
\end{tabular}

\begin{tabular}{lll} 
Chronic kidney disease & & \\
\hline Yes & 19 & 44.2 \\
\hline No & 24 & 55.2 \\
\hline
\end{tabular}

Medication adherence

\begin{tabular}{lll}
\hline High & 31 & 72.1 \\
\hline Moderate & 12 & 27.9 \\
\hline BMI $\left(\mathrm{kg} / \mathrm{m}^{2}\right)$ & & \\
\hline$<25$ & 16 & 37.2 \\
\hline $25-30$ & 14 & 32.6 \\
\hline$>30$ & 13 & 30.2 \\
\hline \multicolumn{3}{l}{ Mean \pm SD } \\
\hline Age $($ years $)$ & $52.9 \pm 14.5$ & 14.5 \\
\hline BMI $\left(\mathrm{kg} / \mathrm{m}^{2}\right)$ & $27.2 \pm 6.0$ & 6.0 \\
\hline SBP $(\mathrm{mmHg})$ & $129.3 \pm 7.9$ & 7.9 \\
\hline DBP $(\mathrm{mmHg})$ & $81.6 \pm 5.9$ & 5.9 \\
\hline OSAHS: obstructive sleep apnea and hypopnea syndrome; BMI: body mass index; SBP: systo-
\end{tabular}

lic blood pressure; DBP: diastolic blood pressure. 


\section{TABLE 2 Association of characteristics of study variables according to the Berlin Questionnaire.}

\section{Characteristics}

Berlin (risk for OSAHS)

$\mathbf{P}^{*}$

Low risk

High risk

n (\%)

\begin{tabular}{|c|c|c|c|}
\hline \multicolumn{3}{|l|}{ Medication adherence } & \multirow[t]{3}{*}{0.9872} \\
\hline High & $13(72.2)$ & $18(72)$ & \\
\hline Moderate & $5(27.8)$ & $6(28)$ & \\
\hline \multicolumn{3}{|l|}{ Epworth Questionnaire } & \multirow[t]{3}{*}{1.0000} \\
\hline Normal daytime sleepiness & $14(77.8)$ & $20(80)$ & \\
\hline Excessive daytime sleepiness & $4(22.2)$ & $5(20)$ & \\
\hline \multicolumn{3}{|l|}{ PSQI } & \multirow[t]{4}{*}{0.0037} \\
\hline Good sleep quality & $11(61.1)$ & $4(16)$ & \\
\hline Bad sleep quality & $5(27.8)$ & $8(32)$ & \\
\hline Sleep disorder & $2(11.1)$ & $13(52)$ & \\
\hline \multicolumn{3}{|l|}{ Ethnicity } & \multirow[t]{4}{*}{1.0000} \\
\hline Caucasian & $11(61.1)$ & $16(64)$ & \\
\hline African descent & $6(33.3)$ & $8(32)$ & \\
\hline Asian & $1(5.6)$ & $1(4)$ & \\
\hline \multicolumn{3}{|l|}{ Sex } & \multirow[t]{3}{*}{0.6555} \\
\hline Female & $12(66.7)$ & $15(60)$ & \\
\hline Male & $6(33.3)$ & $10(40)$ & \\
\hline \multicolumn{3}{|l|}{ CKD } & \multirow[t]{3}{*}{0.9769} \\
\hline No & $10(55.6)$ & $14(56)$ & \\
\hline Yes & $8(44.4)$ & $11(44)$ & \\
\hline \multicolumn{3}{|l|}{ DM } & \multirow[t]{3}{*}{0.7010} \\
\hline No & $14(77.8)$ & $21(84)$ & \\
\hline Yes & $4(22.2)$ & $4(16)$ & \\
\hline \multicolumn{3}{|l|}{$\operatorname{BMI}\left(\mathrm{kg} / \mathrm{m}^{2}\right)$} & \multirow[t]{4}{*}{0.1649} \\
\hline$<25$ & $8(44.4)$ & $8(32)$ & \\
\hline $25-30$ & $3(16.7)$ & $11(44)$ & \\
\hline$>30$ & $7(38.9)$ & $6(24)$ & \\
\hline
\end{tabular}

* Chi-square.

OSAHS: obstructive sleep apnea and hypopnea syndrome; PSQI: Pittsburgh Sleep Quality Index; CKD: chronic kidney disease; DM: diabetes mellitus; BMI: body mass index.

TABLE 3 Association of study groups and means according to the Berlin questionnaire.

Berlin (risk for OSAHS)

Low risk

n (\%)

\begin{tabular}{l} 
Number of medications \\
2 or less \\
More than 2 \\
\hline
\end{tabular}

Age (years)

$\mathrm{SBP}(\mathrm{mmHg})$

$\mathrm{DBP}(\mathrm{mmHg})$

BMI $\left(\mathrm{kg} / \mathrm{m}^{2}\right)$

* Chi-square.

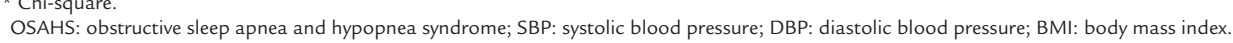

$\begin{array}{ll}12(66.7) & 14(56) \\ 6(33.3) & 11(44)\end{array}$

\section{Mean \pm SD}

$49.3 \pm 16.4$

$55.5 \pm 12.7$

$126.6 \pm 6.6$

$131.4 \pm 8.4$

$79.6 \pm 4.9$

$83 \pm 6.2$

$27.2 \pm 6.4$

$27.5 \pm 6.0$

0.1652

0.0493

0.0585

0.8994 


\section{Discussion}

The groups were similar to each other with regard to age and BMI, but differed in relation to diastolic pressure levels $(\mathrm{p}<0.06)$. In our study, we found no statistically significant difference ( $p>0.48$ ) after administering the BQ when correlating high-risk versus low-risk group for OSAHS and the groups using more than two medications (RHBP) and those using two medications at most. In comparing our data with those reported in the literature, we observed a $64-80 \%$ incidence of association between RHBP and OSAHS as a secondary cause of RHBP. ${ }^{11,20,21}$ We can attribute our findings to confounding factors such as age, sex, height, BMI, cervical circumference, level of education and pseudo-adherence, given that the mean SBP values were $127.5 \pm 6.4 \mathrm{mmHg}$, a mean DBP of $79.6 \pm 5.2 \mathrm{mmHg}$, a mean BMI of $27.2 \pm 5.3 \mathrm{~kg} / \mathrm{m}^{2}$ and a mean age of $51.2 \pm 15.1$ years. In the two-drug group, the mean SBP value was $132.1 \pm 9.3 \mathrm{mmHg}$, the mean DBP was $84.5 \pm 5.8 \mathrm{mmHg}$, the mean BMI was $27.2 \pm 7.2 \mathrm{~kg} / \mathrm{m}^{2}$ and the mean age was $55.5 \pm 13.4$ years, whereas in the group of patients using more than two medications there were no statistically significant differences. These discrepancies between our results and those reported in the literature do not invalidate the BQ's usefulness in screening OSAHS in patients with BP and sleep disorders, since they have a sensitivity of $85.5 \%$ and specificity of $65 \%$ if we consider a cut-off equal to or greater than 10 for the apnea-hypopnea index.

Our study showed a statistically significant correlation between patients at high risk of OSAHS and poor sleep quality, but no evidence of a correlation between daytime sleepiness and risk of OSAHS, since most of the patients with excessive daytime sleepiness had difficulty understanding the situations described in the questionnaire. A high risk of OSAHS was associated with older age ranges, as well as with higher blood pressure levels, but remained statistically significant with the DBP levels.

Comparing the groups, we found no significant association. Despite the fact that even though patients using more than two drugs had a higher risk of OSAHS, the difference was not statistically significant. In this group, we found higher SBP levels and greater ages; these are factors that, per se, are predictive of a high risk of OSAHS. These data reinforce the relation between HBP and OSAHS: $58.14 \%$ of patients with HBP are at a high risk of OSAHS, despite the use of methods less sensitive and specific than polysomnography to assess the existence of obstructive sleep apnea. With respect to RHBP, there should be greater attention from both the general practitioner and the cardiologist, considering that many cases of RHBP are erroneously classified due to low adherence to medication intake. Though sometimes more than three medications are prescribed, the expected decline in pressure levels is not achieved because these patients do not take their medications properly.

\section{Conclusion}

Considering our findings, we conclude that patients at a high risk of OSAHS had poorer sleep quality and higher DBP levels. However, they did not show a higher prevalence of RHBP.

\section{Resumo}

Síndrome da apneia obstrutiva do sono e qualidade do sono em hipertensos

Introdução: A síndrome da apneia e a hipopneia obstrutiva do sono (SAHOS) estão inseridas entre os fatores de desenvolvimento da hipertensão arterial sistêmica (HAS), um relevante problema de saúde pública mundial. A SAHOS é caracterizada pela redução ou cessação completa do fluxo aéreo respiratório, decorrente do colapso intermitente das vias respiratórias. Adicionalmente, observam-se nos pacientes importantes alterações no ritmo e padrão do sono.

Objetivo: Avaliar a associação entre SAHOS e qualidade de sono em hipertensos essenciais e resistentes.

Método: Estudo observacional, transversal avaliou 43 pacientes hipertensos provenientes dos ambulatórios da Faculdade de Medicina do ABC (FMABC) medicados com dois ou mais anti-hipertensivos, divididos em não resistentes ou resistentes ao tratamento.

Resultados: Grupo I (que utilizava até dois anti-hipertensivos $-60,47 \%$ da amostra) apresentou pressão arterial sistêmica (PAS) média de 127,5 $\pm 6,4 \mathrm{mmHg}$, pressão arterial diastólica (PAD) média de 79,6 $\pm 5,2 \mathrm{mmHg}$, índice de massa corpórea (IMC) médio de $27,2 \pm 5,3 \mathrm{~kg} / \mathrm{m}^{2}$ e idade média de $51,2 \pm 15,1$ anos. Grupo II (que utilizava mais que dois anti-hipertensivos $-37,2 \%$ da amostra) apresentou PAS média de 132,1 $\pm 9,3 \mathrm{mmHg}$, PAD média de $84,5 \pm 5,8$ $\mathrm{mmHg}$, IMC médio de $27,2 \pm 7,2 \mathrm{~kg} / \mathrm{m}^{2}$ e idade média de $55,5 \pm 13,4$ anos. Os pacientes apresentaram baixa qualidade de sono/distúrbio do sono avaliada pelo PSQI, o que representa um fator preponderante para SAHOS.

Conclusão: Os pacientes com alto risco para SAHOS tiveram pior qualidade de sono e elevados níveis de PAD, sugerindo uma relação causal entre esses parâmetros. Contudo, não apresentaram maior prevalência de hipertensão arterial resistente. 
Palavras-chave: apneia, síndromes da apneia do sono, apneia obstrutiva do sono, hipertensão, sono.

\section{RefEREnCES}

1. Sociedade Brasileira de Cardiologia, Sociedade Brasileira de Hipertensão, Sociedade Brasileira de Nefrologia. VI Diretrizes Brasileiras de Hipertensão. Arq Bras Cardiol. 2010; 95(1 Suppl.1):1-51.

2. Martinez MC, Latorre MRDO. Risk factors for hypertension and diabetes mellitus in metallurgic and siderurgic company's workers. Arq Bras Cardiol. 2006; 87(4):471-9.

3. Pimenta E, Calhoun DA. Resistant hypertension: incidence, prevalence, and prognosis. Circulation. 2012; 125(13):1594-6.

4. Massierer D, Oliveira ACT, Steinhorst AM, Gus M, Ascoli AM, Gonçalves SC, et al. Prevalence of resistant hypertension in non-elderly adults: prospective study in a clinical setting. Arq Bras Cardiol. 2012; 99(1):630-5.

5. Departamento de Hipertensão Arterial da Sociedade Brasileira de Cardiologia. First Brazilian position on resistant hypertension. Arq Bras Cardiol. 2012; 99(1):576-85.

6. de la Sierra A, Segura J, Banegas JR, Gorostidi M, de la Cruz JJ, Armario P, et al. Clinical features of 8295 patients with resistant hypertension classified on the basis of ambulatory blood pressure monitoring. Hypertension. 2011; 57(5):898-902.

7. Calhoun DA, Jones D, Textor S, Goff DC, Murphy TP, Toto RD, et al Resistant hypertension: diagnosis, evaluation, and treatment. A scientific statement from the American Heart Association Professional Education Committee of the Council for High Blood Pressure Research. Hypertension. 2008; 51(6):1403-19.

8. Epstein LJ, Kristo D, Strollo PJ Jr, Friedman N, Malhotra A, Patil SP, et al.; Adult Obstructive Sleep Apnea Task Force of the American Academy of Sleep Medicine. Clinical guideline for the evaluation, management and long-term care of obstructive sleep apnea in adults. J Clin Sleep Med. 2009; 5(3):263-76.

9. Sleep-related breathing disorders in adults: recommendations for syndrome definition and measurement techniques in clinical research. The Report of an American Academy of Sleep Medicine Task Force. Sleep. 1999; 22(5):667-89.
10. Franklin KA, Lindberg E. Obstructive sleep apnea is a common disorder in the population: a review on the epidemiology of sleep apnea. J Thorac Dis. 2015; 7(8):1311-22.

11. 11.Tufik S, Santos-Silva R, Taddei JA, Bittencourt LR. Obstructive sleep apnea syndrome in the Sao Paulo Epidemiologic Sleep Study. Sleep Med. 2010; 11(5):441-6.

12. Börgel J, Springer S, Ghafoor J, Arndt D, Duchna HW, Barthel A, et al. Unrecognized secondary causes of hypertension in patients with hypertensive urgency/emergency: prevalence and co-prevalence. Clin Res Cardiol. 2010; 99(8):499-506

13. Strohl KP, Novak RD, Singer W, Cahan C, Boehm KD, Denko CW, et al Insulin levels, blood pressure and sleep apnea. Sleep. 1994; 17(7):614-8.

14. McCord JM. Oxygen-derived free radicals in postischemic tissue injury. N Engl J Med. 1985; 312(3):159-63.

15. Cintra F, Tufik S, D'Almeida V, Calegare BF, de Paola A, Oliveira W, et al. Cysteine: a potential biomarker for obstructive sleep apnea. Chest. 2011; 139(2):246-52.

16. Vgontzas AN, Bixler EO, Chrousos GP. Sleep apnea is a manifestation of the metabolic syndrome. Sleep Med Rev. 2005; 9(3):211-24.

17. Yun AJ, Lee PY, Bazar KA. Autonomic dysregulation as a basis of cardiovascular, endocrine, and inflammatory disturbances associated with obstructive sleep apnea and other conditions of chronic hypoxia, hypercapnia, and acidosis. Med Hypotheses. 2004; 62(6):852-6

18. Börgel J, Springer S, Ghafoor J, Arndt D, Duchna HW, Barthel A, et al. Unrecognized secondary causes of hypertension in patients with hypertensive urgency/emergency: prevalence and co-prevalence. Clin Res Cardiol. 2010; 99(8):499-506.

19. Pedrosa RP, Drager LF, Gonzaga CC, Sousa MG, Paula LK, Amaro AC, et al Obstructive sleep apnea: the most common secondary cause of hypertension associated with resistant hypertension. Hypertension. 2011; 58(5):811-7.

20. Logan AG, Perlikowski SM, Mente A, Tisler A, Tkacova R, Niroumand M, et al. High prevalence of unrecognized sleep apnoea in drug-resistant hypertension. J Hypertens. 2001; 19(12):2271-7.

21. Gus M, Gonçalves SC, Martinez D, Abreu Silva EO, Moreira LB, Fuchs SC, et al. Risk for Obstructive Sleep Apnea by Berlin Questionnaire, but not daytime sleepiness, is associated with resistant hypertension: a case-control study. Am J Hypertens. 2008; 21(7):832-5. 